\title{
Além do "silêncio de um oceano". Ideias de Brasil nas representações de um crítico e de artistas e arquitetos italianos depois da Segunda Guerra Mundial
}

\begin{abstract}
Aline Coelho Sanches Corato ${ }^{2}$
RESUMO: Este artigo investiga as ideias de Brasil formuladas em uma seleção de cartas, artigos, fotografias, desenhos, pinturas e mostras, entre 1947 e 1963 pelos arquitetos Lina Bo Bardi e Giancarlo Palanti, pelos artistas Roberto Sambonet e Bramante Buffoni, e pelo crítico de arte Pietro Maria Bardi - italianos imigrados no país após a Segunda Guerra Mundial. $\bigcirc$ novo país é visto como o lugar onde parece possível a realização das promessas da arte e da arquitetura modernas, mas também lugar onde estas se desfazem e transformam-se. $\bigcirc$ objetivo do trabalho é identificar, a partir desses exemplos, indícios de uma postura diante da realidade local, condutora de suas pesquisas sobre um caráter para a produção artística.
\end{abstract}

PALAVRAS-CHAVE: Lina Bo Bardi. Pietro Maria Bardi. Giancarlo Palanti. Bramante Buffoni. Roberto Sambonet

ABSTRACT: This article reflects on the images of Brazil formulated in a selection of letters, articles, photographs, drawings, paintings and exhibitions from the period between 1947 and 1963 by the architects Lina Bo Bardi and Giancarlo Palanti, the artists Roberto Sambonet and Bramante Buffoni, and by the art critic Pietro Maria Bardi - all of them Italians who immigrated to Brazil after the Second World War. The new country is seen as the land where it seems possible to fulfill the modern art and modern architecture promises, but also where such perspectives are undergoing a process of decay and transformation. On the basis of these examples, this article aims to identify a stance towards the local reality that led their search for a character in artistic production.

KEYWORDS: Lina Bo Bardi. Pietro Maria Bardi. Giancarlo Palanti. Bramante Buffoni. Roberto Sambonet.

\begin{abstract}
1. Este artigo é uma síntese do primeiro capítulo da minha tese de doutorado defendida em março de 2012. O trabalho foi desenvolvido com bolsa do Politecnico di Milano, sob orientação do prof. Daniele Vitale (Politecnico di Milano), co-orientação do prof. Renato Anelli (IAU-USP) e contra-orientação do prof. Paolo Rusconi (Università degli Studi di Milano).

2. Professora Doutora na Área de Teoria e História da Arquitetura no Instituto de Arquitetura e Urbanismo, Universidade de São Paulo, São Carlos, SP, Brasil. Email: alinecoelho@sc.usp.br.
\end{abstract}


3. Também Daniele Vitale escreveu sobre um tom profético do discurso de Le Corbusier, em Daniele Vitale (2009).

4. Cf. Le Corbusier (2004, p. 31).

5. Cf. Gio Ponti (2010, p. 233 , tradução minha).

6. Para alguns outros estudos que se debruçaram, de modos diversos, sobre artistas e arquitetos italianos imigrantes no Brasil, ver Renato Anelli (2001); Fernanda Fernandes (2011a, 2011b).

7. Ver Aline Coelho Sanches Corato (2012).
Introdução

A América Latina, como lugar onde realizar os ideais da arquitetura moderna que em outras partes do mundo haviam falido, foi a expressão de um tema complexo que, no entreguerras e após a Segunda Guerra Mundial, fez-se presente nos mundos europeu, norte e latino-americanos. A arquitetura moderna brasileira, em especial, teve um papel importante e em modos diversos compartilhou dessa promessa e alimentou-a.

Como se sabe, desde seu nascimento, a ideia de América uniu-se àquela de uma "terra prometida", da qual se avizinhou uma noção de um território vazio onde construir cidades e arquiteturas. Em 1930, Le Corbusier contava em Précisions da sua experiência na América do Sul com palavras portadoras de uma promessa ${ }^{3}$ :

Tentei a conquista da América devido a um motivo implacável e a uma grande ternura que dediquei às coisas e às pessoas; compreendi, entre esses irmãos separados de nós pelo silêncio de um oceano, a existência de escrúpulos, dúvidas, hesitações, assim como as razões que motivam o estado atual de suas manifestações, e confiei no dia de amanhã. Sob uma tal luz nascerá a arquitetura ${ }^{4}$.

Essa imagem profética foi também reproposta, mais tarde, pelo arquiteto italiano Gio Ponti, em 1957:

Aqui, na felicidade dos trópicos, florescerá a arquitetura moderna, na perfeita condição para esta: em outros lugares a arquitetura é um complicado abrigo, uma toca desprotegida fora da terra: aqui o arquiteto é uma asa protetora sob a qual viver em um Paraíso Terrestre. Venezuela, Brasil: lugares da arquitetura feliz $z^{5}$.

Imediatamente após a Segunda Guerra Mundial, todo o continente recebeu arquitetos e artistas europeus ${ }^{6}$, imigrantes que viam ali a promessa de trabalho e riqueza diante da Europa em crise e, talvez, o lugar de efetivação dos próprios ideais de vida e daqueles da arquitetura e da arte modernas. Entre eles estavam o galerista, jornalista e crítico de arte Pietro Maria Bardi (1900-1999), os arquitetos Lina Bo Bardi (1914-1992) e Giancarlo Palanti (1906-1977) e os artistas Roberto Sambonet (1924-1995) e Bramante Buffoni (1912-1989) - italianos que se dirigiram ao Brasil entre 1946 e 1953. Esses personagens, de gerações e talentos diversos, tiveram suas trajetórias assinaladas pelas batalhas em prol da nova arte e nova arquitetura com cidades em comum como palcos e panos de fundo. Foram acomunados ainda pela origem e pela imigração, por trabalhos compartilhados, e por estarem, enfim, envolvidos no início de sua experiência brasileira pela influência e pelas oportunidades criadas por Bardi e o brasileiro Museu de Arte de São Paulo (MASP), que ele ajudou a fundar e dirigiu?.

A imigração supõe, de modo inevitável, a comparação entre uma situação de partida e outra de chegada. Fora da própria cultura de origem, surge o estímulo ao ato de repensar a si próprio e de elaborar um ponto de vista ligado 
a esse confronto. Das impressões que a nova terra despertou nesses cinco personagens, ao longo dos anos, surgiram cartas, artigos, fotografias, desenhos, pinturas e mostras, baseados em ideias diversas do país e de uma relação entre mundos distantes. Uma seleção desse material, do qual uma parte é inédita, compõe o objeto de análise deste artigo, com o fim de interpretar pistas de uma postura diante da realidade local, condutora de suas pesquisas a respeito de um caráter para a arte e a arquitetura. Tais impressões resultaram em representações do Brasil que, se por um lado, fomentaram uma ideia de promessa, por outro, mostraram um lugar onde os ideais se desfaziam e se transformavam com o tempo e com a experiência da realidade do país.

São Paulo em metropolização e o universo da chegada

São Paulo foi o local de estabelecimento dessas figuras, assim como de outros compatriotas imigrados ${ }^{8}$, graças ao seu rápido processo de urbanização e industrialização e à existência de uma grande comunidade italiana - da qual uma pequena parte havia enriquecido e crescido em prestígio social.

A cidade, então, estava assinalada pelo rápido aumento da população, a partir das migrações internas, especialmente das áreas rurais, e externas, bem como pela crescente influência dos Estados Unidos nos mais diversos campos. No processo de expansão, sem planejamento, dos limites horizontais urbanos, era grande o déficit de moradias, somado à precariedade dos transportes e dos sistemas de água e esgoto ${ }^{9}$, enquanto as áreas mais centrais se verticalizavam ${ }^{10}$, atendendo às novas demandas da classe média, em um complexo processo de substituição das construções pré-existentes.

Do elevado número de edifícios que se erguiam naquela São Paulo em metropolização, os arquitetos, evidentemente, ocupavam-se de apenas uma pequena parte; ainda assim, a cidade significava um verdadeiro banco de provas, laboratório da arquitetura moderna e terreno de confronto de diferentes tradições arquitetônicas ${ }^{1}$.

No início dos anos 1940, a capital paulista trazia, em partes do seu meio artístico, a herança das associações livres de artistas da década anterior ${ }^{12}$, das discussões sobre o papel social da arte e das formas diversas com que se manifestava o legado modernista dos anos 1920, defensor da renovação artística de acordo com as vanguardas internacionais, construída, porém, a partir de uma identidade brasileira, fundada em uma herança ao mesmo tempo indígena, africana e portuguesa; rural, popular, mas também, colonial. A partir da segunda metade da década, seriam criados os novos museus, companhias de teatro, cinemas, galerias de arte e as Bienais, instituições que promoveriam a internacionalização da cultura, realizadas com a contribuição de brasileiros, de estrangeiros recém-chegados e de um
8. Diversas eram as razões pelas quais os italianos imigravam depois da guerra, entre elas, a busca por melhores condições de trabalho $\mathrm{e}$ as dificuldades de afrontar a nova situação política. Em primeiro lugar, partiram os fascistas por causa dos chamados processos de purga e, depois de 1948 , quem era considerado comunista ou socialista pelas discriminações e dificuldades de encontrar trabalho. Ver Andreina De Clementi (2010).

9. Ver Nabil Bonduki (1999).

10. Ver Sarah Feldman (2005).

11. Ver Carlos Alberto Ferreira Martins (2000).

12. Como o Clube dos Artistas Modernos, a Sociedade Pró-Arte Moderna (SPAM) e o Grupo Santa Helena e a Família Artística Paulista. Ver Paulo Mendes Almeida (1976). 
13. Ver Maria Arminda do Nascimento Arruda (2005).

14. A respeito da visão de Bardi sobre o passado, ver Aline Coelho Sanches Corato $(2012 ; 2013)$.

15. Ver Francesco Tentori (1990; 2000).

16. Ver Viviana Pozzoli (2013). A respeito de Bardi, atualmente Paolo Rusconi está recolhendo sua biografia e tratando de sua relação com o fascismo.

17. Ver Zeuler Lima (2013).

18. Alguns títulos sobre biografia de Bo Bardi aparecem nas referências bibliográficas deste artigo, ver Marcelo Ferraz (1993); Laura Miotto; Savina Nicolini (1999); Olivia Oliveira (2002; 2006); Antonella Gallo (2004). Sobre esses acontecimentos ver, em especial, Zeuler Lima (2013).

19. Ver Francesco Tentori (1990; 2000); Olivia de Oliveira (2002).

20. Ver Viviana Pozzoli (2013).

21. Ver Francesco Tentori (1990). mecenato formado por industriais - muitos dos quais descendentes de italianos -, além de famílias proprietárias de terras locais ${ }^{13}$.

Dentre essas instituições, estava o Museu de Arte de São Paulo (MASP), fundado em 1947, fruto da iniciativa do empreendedor, jornalista e político brasileiro Assis Chateaubriand, dono da então maior rede de comunicações do país. Para a empreitada, ele convidou Bardi, que dirigiu o museu, desde a sua fundação até a década de 1990, orientando o seu programa cultural e a formação de sua coleção. Ao contrário do Museu de Arte Moderna (MAM), fundado no ano seguinte por Ciccillo Matarazzo, o MASP foi endereçado como um museu de arte de todos os períodos históricos. Contava aqui, entre outros aspectos- em contraste com certo acento sobre o futuro, então evidente na cultura brasileira-, a particular visão de Bardi sobre o passado: entendido como uma presença necessária na vida cotidiana por meio do qual construir nexos e aprendizado, passado materializado como uma presença nas cidades italianas de sua formação, em que se apresentava como estratificação de tempos, inscritos nas pedras dos seus edifícios ${ }^{14}$.

Nascido em La Spezia, Liguria, Bardi era um jornalista e comerciante de arte autodidata, que havia promovido a arquitetura racionalista e as artes na Itália por meio de seus artigos e críticas, da direção de revistas e de seu papel como proprietário e diretor de importantes galerias em Milão e em Roma. Foi ligado ao fascismo ${ }^{15}$ como um bom número de intelectuais, artistas e arquitetos modernos, que viam o regime como possível apoiador das artes. Apesar dessas ligações, Bardi não foi sujeito aos processos de purga, como esclareceu a historiadora da arte Viviana Pozzoli16.

Em 1946, ele casou-se com a arquiteta Lina Bo, que então carregava consigo a herança figurativa das cidades em que vivera, Roma e Milão, da cultura arquitetônica de sua formação na Scuola Superiore di Architettura romana, em 1939, e dos embates da arquitetura e arte moderna, traduzidos em uma experiência distante do projeto e da construção e mais próxima à escritura e à ilustração de artigos ${ }^{17}$ para revistas de massa e especializadas como a Stile e Domus, ambas assinaladas pelas visões de Gio Ponti quanto as artes, design e arquitetura. No ano do final da guerra, ela fez uma viagem pelo país com o fotógrafo Federico Pattelani, encontrou uma ltália pobre e arruinada e participou do Congresso para reconstrução em Milão. Naquele mesmo 1945, fundou em Milão a revista A, attualità, architettura, abitazione, arte, juntamente com Bruno Zevi e Pagani, contando também com a colaboração de Bardi- três personagens vinculados de maneiras diversas à sua trajetória ${ }^{18}$.

O casal viajou então ao Brasil, chegando ao Rio de Janeiro em outubro de 1946. Não tinha, até então, planos para permanecer no país ${ }^{19}$. Bardi cumpria uma agenda elaborada no Studio d'Arte Palma - galeria que ajudou a fundar e dirigiv em Roma -, de busca de mercados para a arte italiana na América do Sul, articulada a instituições que procuravam oportunidades comerciais com a América Latina $^{20}$. Trazia, por isso, uma coleção de obras com as quais organizou três mostras, duas no Ministério da Educação e Saúde e uma no Hotel Copacabana ${ }^{21}$. 
Construía, dessa forma, ocasiões para venda e para contato com os ambientes culturais e com a intelectualidade local.

Ao constituir a coleção de arte europeia que comporia o acervo do MASP, Bardi aproveitou-se das dificuldades vividas pelo mercado artístico na Europa e do dinheiro dos industriais e donos de terra de São Paulo - por vezes pressionados pelo poder de Chateaubriand. Organizou o museu como lugar da unidade das artes e centro didático, tendo como modelo as experiências norteamericanas - assim como ocorria na ltália do pós-guerra - ecoando as ideias de Hebert Read e John Dewey. $\bigcirc$ museu propôs uma série de iniciativas culturais como escolas, apresentações de balé e música, construindo-se como um ambiente de circulação das culturas local e internacional. Promoveu e reuniu artistas estrangeiros, imigrantes e brasileiros, em conferências e exposições entre as quais, Massaguassu, com desenhos e pinturas de Sambonet, acompanhada de um catálogo com textos e fotografias de Bardi22: um complexo conjunto de posicionamentos e de ideias sobre o Brasil, o primeiro que pretendo analisar neste artigo.

\section{Massaguassu}

Massaguassu é o nome de uma praia de Caraguatatuba, cidade litorânea não muito distante de São Paulo. Quando Sambonet chegou ao país em 1948, viveu um período em uma fazenda ali localizada, propriedade da família de sua esposa à época, Luisa ${ }^{23}$, onde realizou a série que viria a ser exposta no MASP, em março de 1949. O contraste entre a então isolada e pequena Caraguatatuba, representada nas pinturas de Sambonet, e o elegante Centro Novo da capital do estado, onde se localizava o museu no qual seriam exibidas as obras, evidenciava aspectos entrelaçados do Brasil, de um lado pobre, precário e arcaico, e, simultaneamente, em rápido processo de modernização.

Nascido em Vercelli, Piemonte, Sambonet chegava com uma formação ligada, inicialmente, aos cursos noturnos na Academia de Brera, a um ano no curso de arquitetura do Politécnico de Milão, em 1942 labandonado para se dedicar à pintura), e às aulas de afresco com Achille Funi, realizadas após o conflito mundial24. Vinculou-se ao ambiente milanês de pintores modernos, inclusive ao grupo dos fundadores da Galleria di Pittura (financiada por seu pai), interessados nas discussões sobre o cubismo, no impacto da Guernica de Picasso e em seu empenho político, e, enfim, na pergunta sobre como endereçar a arte na Itália do pós-guerra ${ }^{25}$. Na coletiva desse grupo, em janeiro daquele mesmo 1949, expôs o quadro "Luisa". Sua composição não era diversa das pinturas de Massaguassu, mas foi nessa segunda série que a grelha de estruturação, tema importante para o pintor, parece ter sido desenvolvida.

Na organização dos quadros de Massaguassu, figuras e fundo eram delineados a partir dessa espécie de arquitetura - reveladora de um olhar para os primeiros Mondrian - e de manchas de cor que recordavam Cézanne, ao definir
22. Refiro-me a Roberto Sambonet e Pietro Maria Bardi (1949). Para esta análise, utilizei também o texto datilografado em italiano encontrado no arquivo de Roberto Sambonet.

23. Luisa Sambonet, nascida Bernacchi (1924? - 2010).

24. Ver Elisa Camesasca (2006; 2008).

25. Ver Tristan Sauvage (1957). 
os volumes por luz e sombra. As cores eram densas de matéria na qual Sambonet escavava uma nova trama.

Massaguassu talvez seja o primeiro retrato, em pintura, que Sambonet construiu do país. Seus temas representavam o lugar, traduzidos nos modos da arte moderna, e apresentavam a gente - uma mocinha, um homem negro, um caiçara -, suas construções precárias e objetos, os cenários e a cidade, parecendo associar natureza e povo como uma única entidade (Figura 1).

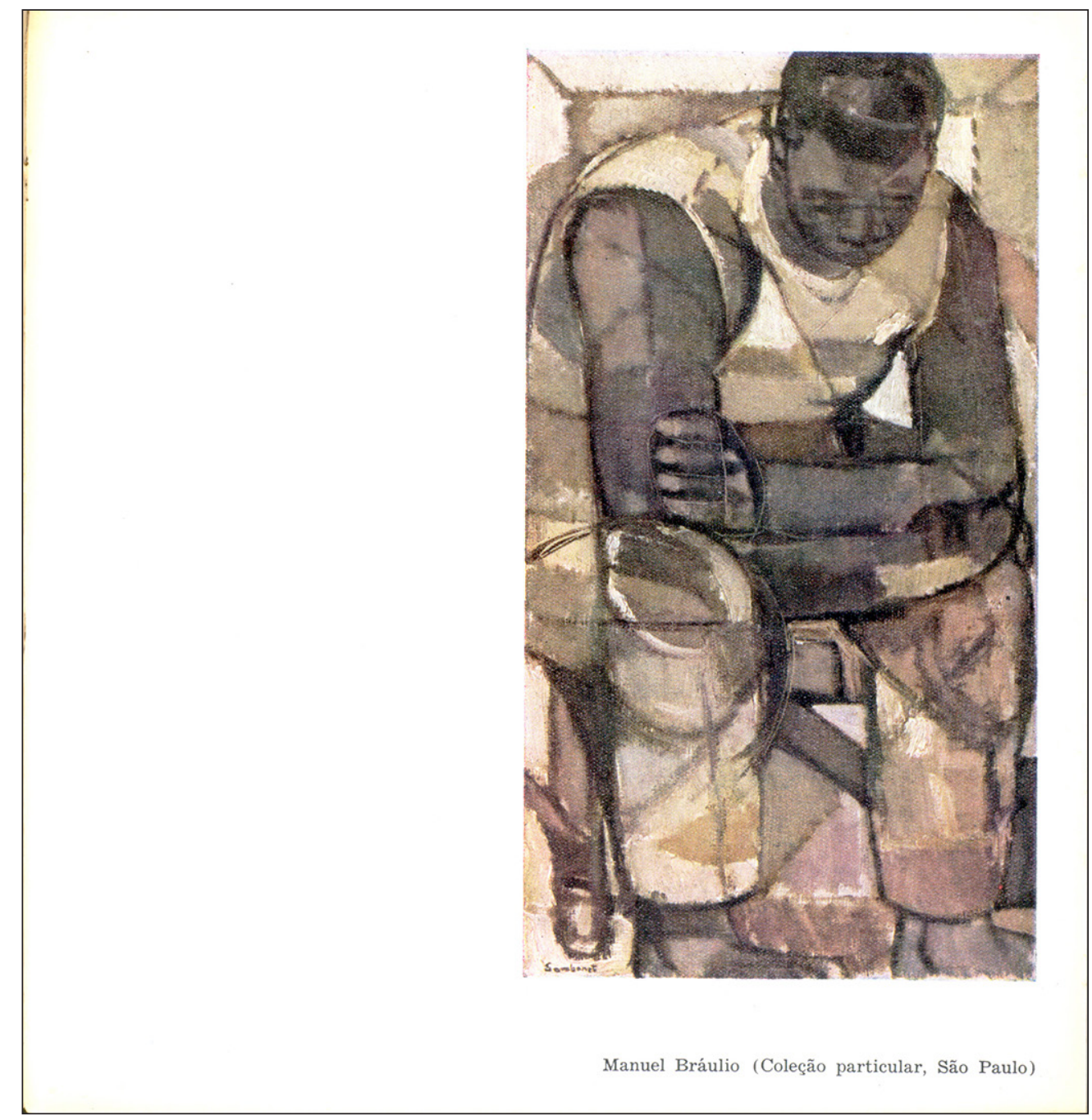

Figura 1 - Página do catálogo assinado por Pietro Maria Bardi e Roberto Sambonet, apresentando o quadro Manuel Bráulio, de Sambonet, 1949.

Sambonet dava monumentalidade a cada figura. Seus personagens nunca olhavam para o observador; tinham sempre a mesma fisionomia serena e desolada, assim como suas paisagens. Assemelhavam-se a esculturas construídas 
com formas geométricas essenciais, com grande valor aos rostos, pés, mãos e braços - capazes de representar qualquer coisa de incontaminado, sem tempo, a ressoar um mundo das origens. Reportavam, de certa maneira, às esculturas de Henry Moore e ao retorno à ordem de Picasso.

Elisa Camesasca ${ }^{26}$, em pesquisa sobre a trajetória de Sambonet, apresenta o que chamou de "palavras-ponte": palavras encontradas nos cadernos de estudo do artista, por meio das quais ele ligava os nomes de muitos pintores ao seu trabalho, além de indicar outras obras de arte como fontes das suas criações. Nas imagens que reproduzem os cadernos escritos em 1993, Sambonet ligava a Massaguassu as palavras "Moore", "Morandi", "Mondrian", "Picasso azul e cubista", "Cézanne", "Leger", evidenciando influências e escolhas.

As pinturas de Massaguassu parecem apresentar a visão do outro e um reconhecimento de si mesmo, revelando a continuidade de visões de arte ligadas ao universo de partida, que começavam a ser reinventadas pela descoberta de um novo mundo e de novos interlocutores.

O texto de Bardi para o catálogo da mostra era portador de uma promessa. Ele via uma possibilidade de redenção da arte no desolamento de Massaguassu: um lugar em estado puro e intacto onde encontrar valores perdidos na grande cidade. Aquele era um mundo incontaminado, com um povo dotado de uma sabedoria em sintonia com uma natureza tranquila e serena, que o diretor do MASP chamou de "Tahiti pessoal" de Sambonet.

Depois de ter vivido os ataques aéreos na ltália, Bardi apresentava os céus daquelas praias "sempre prontos abrir-se em chuvaradas" como uma promessa de liberação. A comparação entre a conjuntura de partida - a ltália em ruínas - e aquela de chegada - um Brasil pleno de possibilidades - aparecia como um motivo dominante do seu texto. Para ele, na Europa ficara o universo de uma pintura desgastada, ligada a discussões improdutivas e superficiais. A permanência de um pintor em Massaguassu significava a oportunidade de "purgar-se" das contaminações do mundo da arte e de descobrir "verdades veladas" que transpareciam no povo e na natureza, para o crítico, fontes de aprendizado.

As fotografias feitas por Bardi em Massaguassu e apresentadas no catálogo demonstravam os temas pelos quais ele se interessava: o povo e seu cotidiano, suas construções, as decorações populares do altar da igrejinha local, o caráter material do lugar e a sua arquitetura, o desolamento da paisagem e sua amplidão (Figura 2). Povo e natureza brasileiros foram temas presentes em diversas ações de Bardi, no museu quanto na Habitat, revista fundada no final de 1950 e dirigida por um período, com sua esposa. A natureza o maravilhava, como em geral ocorria com os europeus ao descobrirem o exuberante ambiente tropical. À descrição da gente do lugar, Bardi adicionava as ideias de força, serenidade e felicidade.

olhar do diretor do MASP em direção ao mundo popular dava prosseguimento a interesses iniciados na ltália e que ecoavam com aqueles de artistas, arquitetos, literatos e intelectuais italianos do entreguerras e do pós-guerra,
26. Ver Elisa Camesasca (2006). 
27. Ver Michelangelo Sabatino (2008).

28. Agradeço a observação feita por Paolo Rusconi sobre Bardi e Le Corbusier.

29. Ver Daniele Vitale (1982).

30. Ver Antonio Gramsci (2007). voltados a documentar e proteger aquele universo e fazer dele matéria de inspiração artística. Essa foi uma pesquisa revestida de palavras, segundo Michelangelo Sabatino ${ }^{27}$, como mediterraneidade, neorrealismo, organicismo e, enfim, arquitetura menor, que teve entre os seus exemplos mais famosos a Mostra da arquitetura rural, organizada por Giuseppe Pagano e Guarniero Daniel na VI Trienal de Milão de 1936. Nessa exposição, as construções rurais eram apresentadas em oposição à retórica classicista e em coerência com aqueles valores da arquitetura racionalista de necessidade e economia, com destaque ao seu caráter anônimo e coletivo. Mas Bardi foi influenciado também, como esclarece Paolo Rusconi28, por aquele Le Corbusier interessado pela arte popular, arquiteto cujas ideias ele admirava.

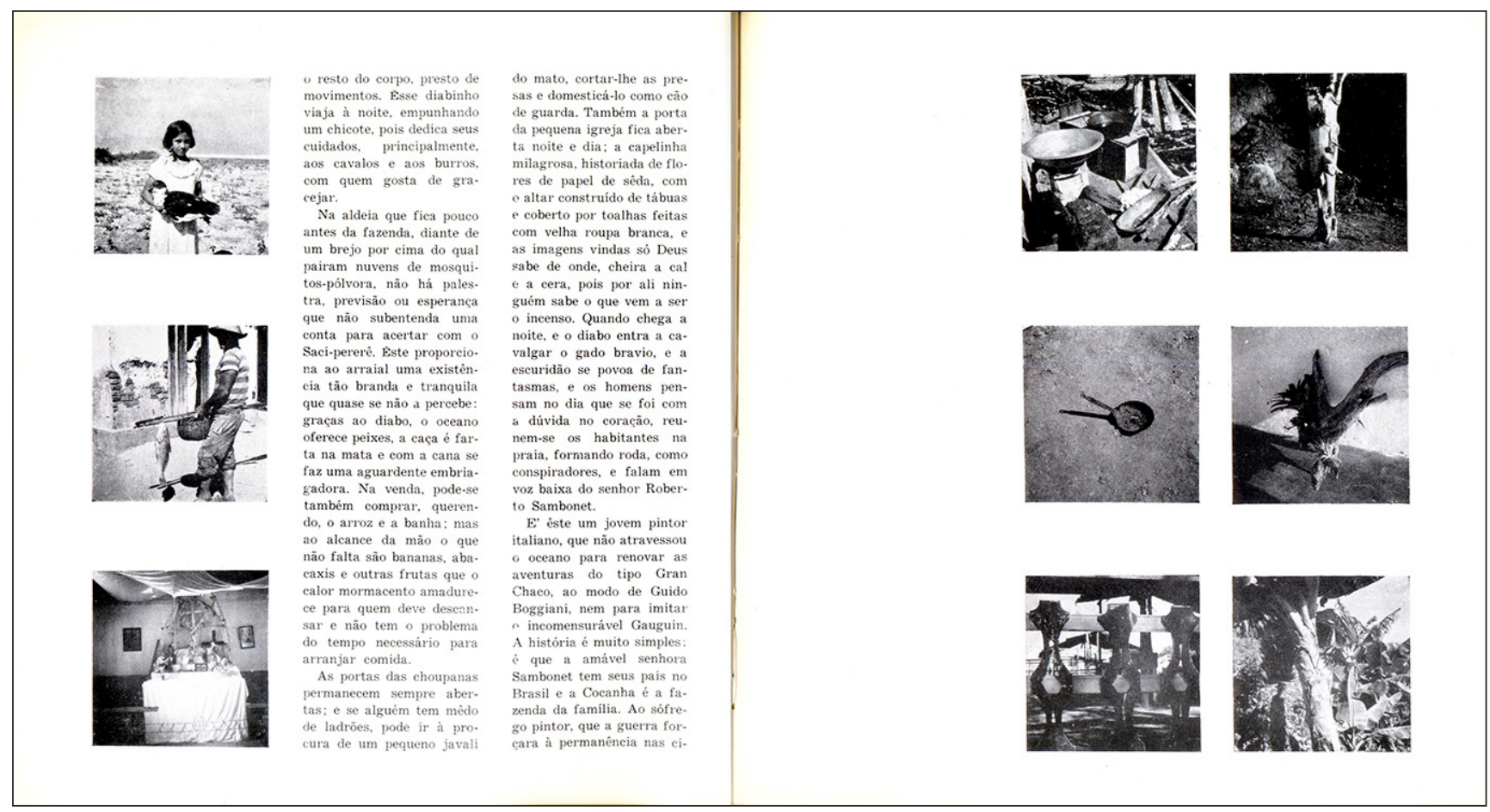

Figura 2 - Página do catálogo assinado por Pietro Maria Bardi e Roberto Sambonet, apresentando fotografias de Bardi. (C) Instituto Lina Bo e P. M. Bardi.

De grande importância na condução desse interesse pelo popular na Itália foi o pensamento de Antônio Gramsci, como relembra Daniele Vitale29, quando trata da experiência ideológica neorrealista. Como se sabe, nos Quaderni del Carcere, escritos entre 1933 e 1935, Gramsci convocava os intelectuais e o povo a conduzir um papel específico, falava de um sentimento "nacional-popular" e distinguia o popular do folclórico ${ }^{30}$. As anotações dos Quaderni foram publicadas pela primeira vez no intervalo entre 1948 e 1951, pela editora Einaudi, agrupadas por temas, com grande impacto sobre o mundo da cultura. Em torno desses escritos, formou-se um clima de discussão que o casal Bardi conheceu e ao qual respondeu, com o tempo, a seu modo. 
$\bigcirc$ povo do texto de Bardi no catálogo era constituído pelos negros, índios e mulheres imigrantes do Nordeste do Brasil, personagens colocados às margens na sociedade brasileira e que ele encontrava em Massaguassu. Reconhecia ali uma situação de pobreza e isolamento, mas o tom de seu texto naquele momento não era de denúncia ou de crítica ao processo histórico que a havia gerado, mas de valorização de um saber, ponto de partida para a criação.

Para Bardi, tal como a burguesia, esse povo deveria ser educado à arte, entendida como fonte de prazer. E ele reproduzia, no catálogo, os desenhos feitos pela gente do lugar sob inspiração do trabalho de Sambonet, prosseguindo com um interesse demonstrado desde a ltália pela chamada arte naif, quando promoveu pintores do gênero em seus artigos e ações ${ }^{31}$.

A apresentação das pinturas de Massaguassu foi, também, a ocasião para Bardi trazer à tona o debate sobre a arte abstrata, em pauta naquele ano, quando se organizou a exposição Do figurativismo ao Abstracionismo no MAM de São Paulo, inaugurada poucos dias antes de Massaguassu, com curatela do crítico belga Léon Degand. Como resposta, o MASP organizou uma Mostra Didática seção especial do museu, dedicada a explicar temas da arte $^{32}$ - sobre a abstração na história. No texto do catálogo de Massaguassu, Bardi defendia a figuração e exaltava aquilo que chamava de sua "capacidade de ensinar". Apesar de ser um amante das artes figurativas, ele conhecia muito bem a arte abstrata - as obras do abstracionismo comasco, por exemplo, encontraram lugar na Quadrante, revista que ele fundou e dirigiu com o escritor Massimo Bontempelli, entre 1933-36. Ainda que a sequência de exposições que o MASP havia realizado, até então, revelasse uma predileção por obras figurativas, contemplava também a arte abstrata. Em 1948, ocorreu a exposição de Alexander Calder; em 1950, as Fotoformas, de Geraldo de Barros; e, em 1951, aquela dedicada à obra de Max Bill, grande estímulo ao movimento concretista de São Paulo.

Pouco tempo depois desta última série, em 1952, a praia de Caraguatatuba voltou a ser tema de outros desenhos de Sambonet, como a aquarela e nanquim intitulado Massaguassu, cabanas de canoas, revelando uma nova preocupação: representar a natureza brasileira, restituindo-the as linhas de construção e o tecido interno traduzido em um esquema gráfico sintético. Era também essa a alma dos desenhos do livro 22 cause + 1, publicado em 195333, quando Sambonet retornou à Itália, e Massaguassu foi novamente um universo de estudos revisitado. $\bigcirc$ livro era uma comunhão dos desenhos do artista, das palavras do poeta italiano Emilio Villa e da gráfica do designer suíço Max Huber. Trazia uma mensagem: a natureza e o povo brasileiros, de novo vistos quase como uma única realidade, eram capazes de ensinar "verdades" - em reprodução às palavras de Bardi -, de revelar estruturas arquetípicas e elementos geométricos sem tempo, de dar à luz os valores das coisas simples. Parece evidente, nesses desenhos, a presença das ideias de Villa, também ele imigrado ao Brasil entre 1951 e 1952, com larga influência no ambiente do MASP, com sua proposta de se aprender da leitura das estruturas da natureza, das formas e imagens
31. Sobre o interesse de Bardi pelos pintores naif na Itália, ver Paolo Rusconi (2009).

32. A respeito das Mostras Didáticas, ver Stela Politano (2010).

33. Ver Roberto Sambonet; Emilio Villa; Max Huber (1953). 
34. Ver Giancarlo Palanti (1947).

35. Ver Adriana Tiso (2009).

36. Architetti Riuniti [AR]: Franco Albini, Ludovico Belgiojoso, Piero Bottoni, Ezio Cerutti, Ignazio Gardella, Gabriele Mucchi, Giancarlo Palanti, Enrico Peressuti, Mario Pucci, Aldo Putelli e Ernesto Nathan Rogers.

37. Sobre a obra de Palanti no Brasil, ver Angela Maria Rocha (1991); Aline Coelho Sanches (2004).

38. Ver Paolo Nicoloso (2001) e Franco Bunçuga (2000).

39. Ver Roberto Cenati; Antonio Quatela (2009). Sobre o papel do Politécnico, ver também Il Politecnico di Milano nella storia italiana, 1914-1963 (1988). daquilo que não era, como ele explica no texto de 22 cause +1 , o Brasil dos estereótipos e mesmo o Brasil norte-americano, mas do que ele denominava terra onde os primórdios não desapareciam.

Quando retornou definitivamente à Itália, em 1953, influenciado pelas atividades do museu de Bardi, especialmente de suas escolas, Sambonet passou a trabalhar como designer e gráfico e a construir uma premiada carreira, fazendo do período brasileiro um momento-chave de sua formação, mesmo que reconfigurado por outras experiências.

Notícias dos trópicos

A correspondência entre os personagens emigrados e seus caros amigos que haviam permanecido na Itália, ainda que menos complexa que as obras de arte e destinada a um único e específico interlocutor - com a liberdade e os direcionamentos que isso implica -, é rica em perspectivas para se entender os interesses e as ideias que se construíam sobre Brasil, além de mostrar aspectos do universo local, que só poderiam ser observados por um olhar distanciado.

Em uma carta escrita em 194734, o arquiteto Giancarlo Palanti apresentava ao ainda sócio, Franco Albini, os seus primeiros juízos sobre São Paulo.

Nascido em Milão, Palanti formou-se no Politécnico da mesma cidade e fez parte daquela geração de arquitetos racionalistas à qual pertenceu Ernesto Rogers, o próprio Albini e Ignazio Gardella, entre outros colegas com quem dividiu discussões e trabalhos. Colaborou com Gio Ponti, conforme informação trazida por Adriana Tiso ${ }^{35}$, e com a revista Domus, além de ser redator da Casabella, quando esta última tinha como diretores Edoardo Persico e Pagano. Participou de algumas obras-chave da história da arquitetura moderna italiana como o Salone d'Onore da VI Trienal de Milão, com Persico e Marcello Nizzoli, e do plano para a reconstrução de Milão chamado AR (Architetti Riuniti) - um manifesto do racionalismo, realizado durante a guerra e elaborado por um grande grupo de arquitetos ${ }^{36}$. No Brasil, Palanti seria responsável por arquiteturas, algumas das quais importantes obras da paisagem de São Paulo, planos urbanísticos e objetos de design ${ }^{37}$.

Os anos do final do conflito foram atribulados para ele. Participou da Resistência junto a Giancarlo De Carlo no Movimento Unità Proletária (MUP) [Movimento Unidade Proletária], ligado ao Partito Socialista di Unità Proletaria (PSIUP) [Partido Socialista de Unidade Proletária], no interior das Brigate Matteotti [Brigadas Matteotti] ${ }^{38}$. Com Giulio Minoletti, ambos assistentes no Politécnico, foi um dos mais ativos animadores do movimento na Universidade ${ }^{39}$. A documentação dos arquivos da escola mostra as dificuldades vividas no período e as sofridas perseguições da polícia fascista. Em sua orientação, podem ter pesado os juízos do amigo Pagano, que, após ter aderido ao fascismo, passou à Resistência até morrer no campo de concentração de Mathausen. Palanti também participou do 
Comitatto di Liberazione Nazionale (CLN architetti) [Comitê de Liberação Nacional - arquitetos] ${ }^{40}$.

Em outubro de 1946, o arquiteto desembarcou no Brasil rumo a novas possibilidades de trabalho, diante das dificuldades encontradas na ltália. Em São Paulo, estavam os familiares da então noiva. Eles the dariam encomendas, assim como seus conhecidos e a colônia italiana. A cidade parecia oferecer oportunidades, com seu enorme número de construções, mas logo o arquiteto percebeu que a situação não correspondia às suas expectativas e eram grandes as dificuldades de exercício da profissão no país, apesar das promessas e realizações da arquitetura moderna.

Para ele, os principais problemas eram a falta de hábito do pagamento pelo projeto como produto autônomo da direção das obras e a necessidade de ter uma empresa de construções a fim de se conseguir algum lucro. Era precário o modo de construir, os operários não possuíam qualificação e eram raros os materiais de qualidade. Apesar de tudo, Palanti esperava que a quantidade com que se edificava na cidade pudesse compensar as somas reduzidas pagas aos projetos.

Difícil era, também, obter o reconhecimento do título de arquiteto, e necessárias eram as diversas manobras para se poder trabalhar: associar-se a outro profissional brasileiro que assinasse os projetos, ou ser assumido em uma empresa de construções ${ }^{41}$.

A carta a Albini revelava as impressões do mundo artístico e intelectual brasileiro, a vontade de aproximar-se e inserir-se nele, a abertura e os interesses do arquiteto na descrição daquilo que chamava "ambiente espiritual". Apesar de reconhecer uma situação que the parecia menos viva que a italiana, encontrava no país quem seguia "ideias análogas" às suas, isto é, aqueles que caminhavam pelas trilhas da linguagem moderna, seja na arquitetura ou na pintura. Ele não mencionava um arquiteto em especial, mas tantos pintores que acreditava estarem no mesmo nível dos melhores italianos e, entre eles, listava os nomes de Candido Portinari, Lasar Segall, Di Cavalcanti, Alfredo Volpi e Aldo Bonadei. Interessado por todos os campos do trabalho artístico, Palanti elogiava os escritores locais e mencionava as dificuldades de entrar em contato com as velhas famílias brasileiras, às quais pertenciam importantes pessoas da cultura.

Eram diversas e complementares as descrições que o artista Bramante Buffoni fazia ao poeta italiano Alfonso Gatto, alguns anos depois. Em cartas, escritas entre 1953 e 195542, Buffoni destacava a participação dos italianos de diversas gerações em instituições de cultura de São Paulo e focalizava outros aspectos do mundo local.

Buffoni nasceu em Giulianova, Abruzzo. Sua formação ligou-se às artes aplicadas, decorativas e à pintura. Órfão, após ter as primeiras lições em uma fábrica de cerâmicas, estudou na Escola de Artesanato de Pesaro e nas Escolas de Artes de Roma e Florenç ${ }^{43}$, quando então se deslocou para a Lombardia e terminou sua formação, em 1934, no Istituto Superiore Industrie Artistiche (ISIA) [Instituto Superior para Indústrias Artísticas] de Monza, como um dos alunos mais talentosos.
40. Ver Paolo Nicoloso (2003).

41. Naquele momento, os arquitetos estrangeiros, caso não fossem formados no país, deveriam realizar um complexo exame de revalidação do diploma ou naturalizar-se para poderem assinar seus projetos. A res-peito disso, ver os estudos sobre arquitetos estrangeiros: Anat Falbel (2003); Aline Coelho Sanches (2004); Joana Mello de Carvalho e Silva (2010).

42. Ver Bramante Buffoni (1953; 1954; 1955).

43. Ver Pietro Maria Bardi e Regina Helena Sarapo (1987). 
44. Ver Alessandro Parronchi (2004).

45. Sobre Buffoni ainda não existe monografia alguma e não se conhecem muitas passagens da sua vida. Mas a seu respeito, ver os esforços de análise e sistematização de sua biografia em Adriano Tomitão Canas (2010); Aline Coelho Sanches Corato (2012); Isabel Ruas (2014). Ver também Marco Rinaldi (1999), que tratando da obra de Gastone Novelli, traz informações sobre Buffoni.
Colaborou imediatamente com Nizzoli e Persico e participou das Trienais de Monza e Milão e da Feira de Milão. Para a revista fundada por Gatto e pelo escritor Vasco Pratolini, Campo de Marte, fez algumas ilustrações ${ }^{44}$. Obteve reconhecimento no ambiente de produção gráfica milanesa, trabalhou para a Pirelli e a Olivetti, com as quais colaboraria também no Brasil, onde chegou em maio de 1953, passando a ser professor, gráfico, artista de painéis e murais para a arquitetura moderna em São Paulo (ałuou em diversas ocasiões com Palanti), pintor, e designer de produtos ${ }^{45}$.

Recém-chegado a São Paulo, Buffoni em sua carta contava a Gatto das articulações de Bardi para sua inserção no país: um grande artigo a ser publicado na Habitat, um curso de gráfica criado para ele no museu e notas publicadas nos jornais de Chateaubriand a respeito de sua atuação. Palanti o apoiava e com seu amigo, o cenógrafo italiano Aldo Calvo, imigrado para o Brasil em 1947, recomendaram-no a Matarazzo, que naquele momento já era responsável pelas festividades de comemoração do IV Centenário da Cidade e pela segunda Bienal. Enfim, falava de suas primeiras percepções a respeito do universo cultural de São Paulo: duas facções em disputa, a de Matarazzo, de um lado, e a de Chateaubriand e Bardi, de outro.

Buffoni nunca mencionou artistas brasileiros na correspondência com Gatto. Nas primeiras cartas, contava sobre o povo e a cidade, que the parecia um "eldorado", aonde todos iam em busca de fortuna, repleta de conterrâneos ainda fascistas, de "vendedores" de certa "genialidade italiana" e europeus a explorar um país que ainda se comportava como colônia.

O artista falava da periferia de São Paulo e construía uma interpretação particular das contradições do país no qual se evidenciava o olhar habituado ao passado e espantado com o confronto entre novo e antigo, entre desenvolvimento material acelerado e o que ele chamava de forma mentis atrasada, e a falta de uma "tradição", tal como ele via na ltália.

No final de 1953, Buffoni referiu-se a seus interesses, em função dos trabalhos, pela fauna e pela flora do Brasil, descrevendo a terra, as formas "estranhas" das árvores, os frutos e flores "monstruosas", as cores "violentas", a bela exuberância "de desenhos impensáveis", a mistura das raças e as mulheres, o "espiritismo", a música e a dança- estes três últimos, para ele, únicos aspectos "espontâneos". Falava da sua vontade de visitar a Bahia e Pernambuco para encontrar os "lugares autênticos" da cultura e do que chamava de "verdadeiras tradições" e pintar suas figuras e paisagens. São Paulo daqueles anos não oferecia mais ao artista, como ele gostaria, o que acreditava ser o Brasil verdadeiro; ao invés disso, havia uma cidade em contínua transformação, com uma hegemonia sempre maior dos Estados Unidos sobre o mundo cultural, econômico e social, argumento frequente em suas cartas.

Um novo mundo formal começava a povoar suas primeiras obras brasileiras, entre as quais um grupo de painéis em madeira, inicialmente preenchido com uma grossa camada de tinta preta para, então, ser escavado, deixando 
evidente o material original, capaz de revelar perfis de animais e índios brasileiros (Figura 3). Esse interesse de Buffoni pelo que chamava de "autêntico" ou "verdadeiro" talvez fosse um eco das pesquisas das vanguardas europeias, mas ressoava, sobretudo, sua experiência do ISIA de Monza e a busca pelos arquétipos dos seus anos de formação - quando, em seus desenhos e gráficas, tais modelos derivavam de um mundo original e antigo. Indicava, enfim, um eco do ambiente italiano voltado ao popular, do neorrealismo, que se reconfigurava na busca pela periferia de São Paulo ou pela Bahia e pelo Nordeste.

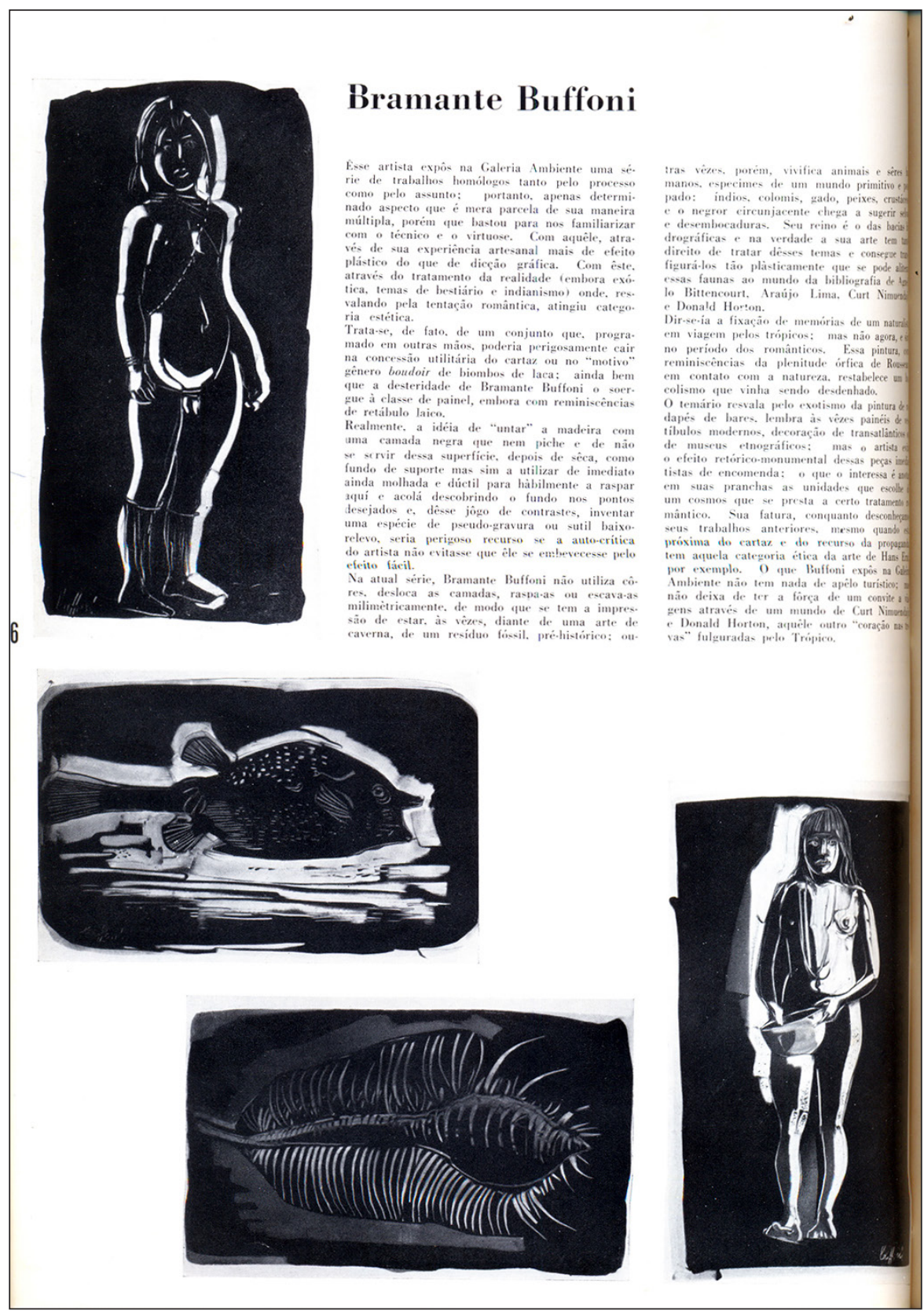

Figura 3 - Obras de Bramante Buffoni retratando figuras de índios e animais brasileiros, Habitat, n. 20, 1955 
46. Ver Renato Anelli; Abilio Guerra; Nelson Kon (2001).
Em outubro de 1954, Milão para Buffoni parecia uma realidade distante, ainda que "viva nos sentimentos", quando o pintor declarou então seu apreço às pessoas e cidades brasileiras, com seus defeitos e qualidades. Mas, em maio de 1955, comunicava o seu desejo de voltar à Itália, incomodado com o excesso de influência americana direcionada ao consumismo no Brasil. Sua conclusão era que partira pobre e retornaria pobre. Buffoni permaneceria no Brasil, morrendo em São Paulo, em 1989. Retratou o país muitas vezes e em modos diversos.

As representações do Brasil feitas por esses personagens apareceriam, também, em revistas de arquitetura italianas, para as quais eles enviavam escritos, projetos e imagens. Exemplo disso foi um conjunto de fotografias feitas por Palantie escolhidas provavelmente por seus redatores e por seu editor, utilizado para abrir a sessão especial da revista Zodiac, de 1960, Rapporto Brasile [Relatório Brasil] (Figura 4).

Assim como outras imagens encontradas no arquivo pessoal de Palanti, elas retratavam a natureza, as construções e os objetos do povo dos arredores de Santos, provavelmente vizinhos a Massaguassu, que permanecera, como outros lugares do litoral de São Paulo, como uma espécie de mito para muitas dessas figuras italianas. Mostravam árvores e plantas como estruturas geométricas, sem profundidade de campo e com grandes contrastes entre preto e branco. As tramas dos objetos e construções populares eram apresentadas de modo similar aos desenhos de Sambonet em 22 cause +1 , como se houvesse um comum interesse e um comum modo de ver, curiosamente semelhante às fotografias brasileiras de outro imigrado, o arquiteto austríaco Bernard Rudofsky, que veio da Itália, permaneceu no Brasil entre 1938 e 1941, e seguiu para os Estados Unidos.

Em uma das imagens publicadas na Zodiac, Palanti colocava em primeiro plano o tronco cortado de uma árvore, transformado concomitantemente em mesa e apoio de objetos domésticos cotidianos. $\bigcirc$ arquiteto estava interessado pela maneira criativa, derivada da grande dificuldade de meios, de utilizar aquilo que era disponível e via nos objetos do povo, fruto da pobreza material e da necessidade de construir instrumentos de sobrevivência, uma simplicidade e uma "racionalidade" que os avizinhavam dos valores da arte moderna.

Seu arquivo revela duas outras fotografias que contribuem para entender o contexto da composição de suas imagens: uma o retrata em meio à natureza brasileira com seus instrumentos de estudo e a outra o mostra em companhia de Sambonet e do arquiteto Rino Levi na área rural. Levi, grande amigo de Roberto Burle-Marx, a quem confiaria os jardins de muitos dos seus projetos ${ }^{46}$, participara de diversas excursões do paisagista em exploração da natureza no interior do território brasileiro, a fim de encontrar novas espécies de plantas e de reconhecer o caráter da paisagem, fazendo deles elemento de criação.

Natureza e paisagem foram termos decisivos do modernismo no Brasil e suscitaram, do mesmo modo, o interesse desses imigrantes que os interpretaram e os repropuseram de maneiras diferentes. A tensão entre descoberta e criação que 


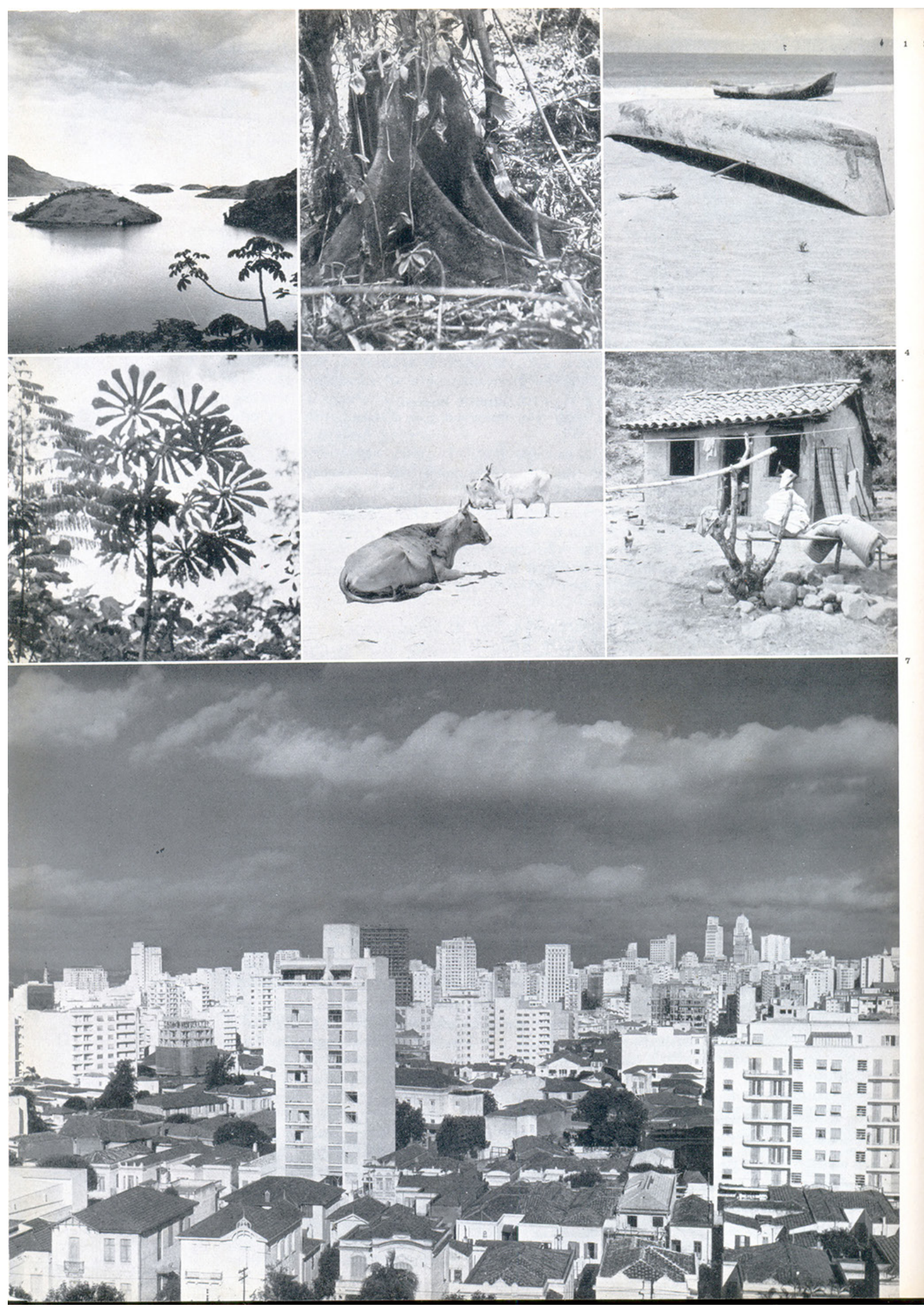

Figura 4 - Página de abertura do especial Rapporto Brasile, da revista Zodiac, n.6, 1960, apresentando, no alto, fotografias de Giancarlo Palanti no entorno de Santos e, embaixo, foto de Boer mostrando o edifício Lilly, projeto de Palanti, em meio ao boom de construções de São Paulo. 
47. Ver Juliano Pereira (2008).

48. Sobre os textos de Bo Bardi, ver também Silvana Rubino; Marina Grinover (2009).

49. Cf. Lina Bo Bardi (1956, p. 182, tradução minha).

50. O livro foi publicado em alemão como Brasilien. Ein Land der Zukunft. Stockholm: Bermann-Fischer, 1941. No mesmo ano, teve edição brasileira, Brasil, um país do futuro, e foi republicado posteriormente com. prefácio de Alberto Dines, cf. Stefan Zweig (2008). A primeira edição italiana é de 1949, Brasile: terra dell'avvenire, com tradução de Mario Merlini. Milano: Sperling and $\mathrm{Ku}-$ pfler, 1949.

51. Ver Claude Lévi-Strauss (1955). Vale observar que a edição italiana saiu cinco anos mais tarde, em 1960, depois da edição brasileira, de 1957.

52. Cf. Lina Bo Bardi (1956, p. 183 , tradução minha). animava a pesquisa de Burle-Marx alimentava, por vias diversas, as obras dos italianos aqui estudados. Não parece um acaso que, em 1952, Bardi tenha dedicado ao paisagista uma mostra individual no MASP e uma monografia com fotografias de Marcel Gautherot, publicada em 1964, em Milão. Bo Bardi exporia as pinturas e fotografias de Burle-Marx em 1960, quando dirigia o Museu de Arte Moderna da Bahia (MAMB), em Salvador ${ }^{47}$. Antes disso, em 1956, o paisagista seria apresentado por ela como exemplo de um caminho da produção brasileira, em seu artigo Lettera dal Brasile [Carta do Brasil], publicado na revista dirigida por Bruno Zevi, L'architettura Cronache e Storia.

Carta do Brasil

A palavra e o desenho foram importantes instrumentos de reconhecimento do mundo e de construção do pensamento para Bo Bardi, que escrevia e desenhava muito bem ${ }^{48}$. Quando deixou a Itália, em setembro de 1946, com o marido, desenhou Nápoles na partida. Na chegada ao Brasil, desenhou Recife e Olinda, vistos do mar e assinalados pelo verde e azul. O navio aportou no Rio de Janeiro, mas o encontro com o país seria descrito mais tarde.

"Como é o Brasil para o europeu que desembarca pela primeira vez no Rio de Janeiro?" 49 ela se perguntava em Lettera dal Brasile,uma pergunta-chave que teve na história variadas respostas, como a maravilhada descrição de Stefan Zweig no seu Brasil, país do futuro ou aquela de Claude Lévi Strauss em Tristes trópicos ${ }^{51}$.

Bo Bardi explicava que o artigo fora escrito por solicitação de amigos que the davam notícias das críticas à arquitetura brasileira publicadas em jornais italianos. Como se sabe, desde 1954 cresciam as objeções a essa arquitetura, transformada em verdadeiro caso de projeção internacional por meio das publicações nas revistas Casabella-Continuità e Architectural Review, com opiniões diversas de figuras como Rogers, Max Bill e Walter Gropius. A arquiteta pedia em seu artigo que a arquitetura brasileira fosse julgada, em função dos problemas reais de vida e do ambiente que condicionavam as construções do país e, em resposta à sua própria pergunta, explicava:

Do avião, o contraste entre os barracos dos negros e as construções modernas diz respeito mais ao caso social que ao ressentimento burguês pelo arranha-céu estandardizado no lugar da casinha em estilo. Do navio, a entrada de Copacabana e da baía com o Ministério da Educação e os outros edifícios que aparecem de improviso, quase grudados na floresta de onde chega a bordo o perfume, sugerem um esforço humano que não deixa tempo para pensar se era melhor o arranha-céu ou a casinha folclórica portuguesa ${ }^{52}$.

A coleção de imagens escolhida por Bo Bardi para ilustrar o artigo pretendia mostrar uma condição de precariedade de lugares menos conhecidos do Brasil e a urgência em construir. Evidenciava a necessidade de uma luta cansativa contra uma natureza vigorosa, violenta e exuberante, e, enfim, a obra 
de Burle-Marx, apresentado como o grande exemplo da cultura brasileira. Entre imagens de seus jardins, painéis figurativos e totens, uma das fotografias mostrava o projeto do paisagista para Copacabana, descrita como representante da luta do Brasil pela modernização (Figura 5).

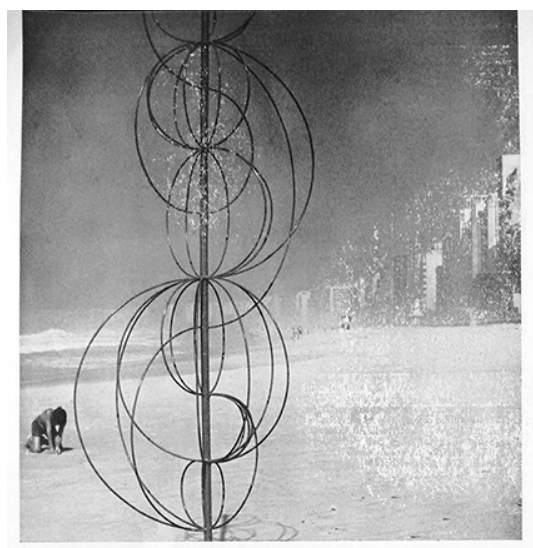

Lettera dal Brasile

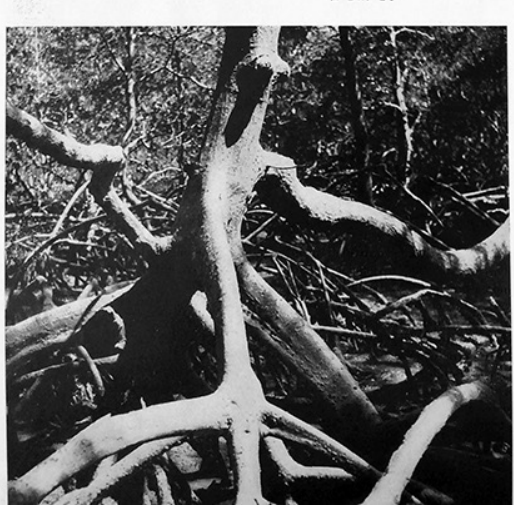

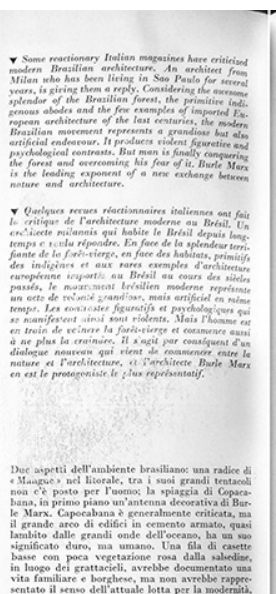
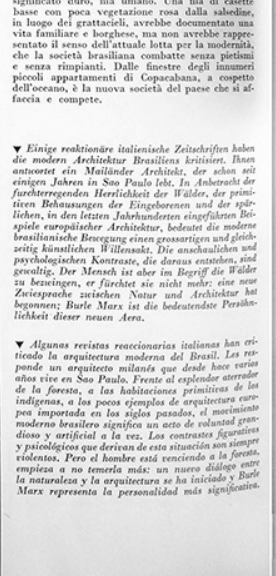

53. Cf. Lina Bo Bardi (1956, p. 186, tradução minha).

Figura 5 - Aspecto da seleção de imagens de Lina Bo Bardi para o seu artigo Lettera dal Brasile, em L'Architettura Cronache e Storia, n.9, 1956. A primeira fotografia apresenta a praia de Copacabana com escultura de Burle-Marx.

Em uma das páginas, por exemplo, Bo Bardi colocou lado a lado a fotografia de uma arquitetura de Costa e Niemeyer, outra de uma casa do início do século - sobrevivente entre os arranha-céus de São Paulo - e, enfim, aquela de um carro de boi, máquina com uma técnica secular ainda em uso no país, descrita como a voz do Brasil antigo. Esta e outras imagens queriam apresentar o contraste entre o desejo de modernização e o arcaísmo de condições presentes, as grandes dificuldades e as enormes distâncias do país a serem vencidas pela necessidade de construção. Com isso, a arquiteta solicitava aos jornais italianos "um átimo de meditação e não a liquidação esnobe da pseudocultura" ${ }^{\prime \prime}$.

Essa mesma febre de fazer tudo rapidamente é que havia, para Lina, contaminado a arquitetura brasileira. Mas dessa arquitetura ela destacava também 
54. Cf. Lina Bo Bardi (1956, p. 187 , tradução minha).

55. Ver Lina Bo Bardi (1951).

56. A respeito do Curriculum, ver Renato Anelli (2010).

57. Cf. Lina Bo Bardi (1993, p. 12).

58. Idem, ibidem. os méritos, fundados em "soluções construtivas simples e frescas, uma modéstia unida a um sentido festivo da vida" 54 e profetizava uma nova fase, a partir dos estudantes recém-formados. Não era a primeira vez que a arquiteta exprimia seu juízo sobre o assunto: em 1951, ela comparara a arquitetura brasileira a uma bela criança que não tinha suas raízes na arquitetura jesuítica, mas naquela popular ${ }^{55}$, construindo, assim, sua origem e uma perspectiva futura.

Alguns anos depois, Bo Bardi retomaria a resposta para a pergunta colocada no início de sua Lettera. Em um texto de difícil análise, porque fruto da combinação de trechos escritos em tempos diversos e publicado postumamente, o chamado Curriculum literário ${ }^{56}$, narrava sua chegada ao Rio por mar, em que se reconhecem trechos da Lettera e outras adições. Com palavras cheias de esperança, ela reforçava nesses discursos uma visão do país como terra prometida e lugar de construção da arquitetura moderna, "um farol de luz a resplandecer em um campo de morte" 57 :

Chegada ao Rio de Janeiro de navio, em outubro. Deslumbre. Para quem chegava pelo mar, - Ministério da Educação e Saúde avançava como um grande navio branco e azul contra o céu. Primeira mensagem de paz após o dilúvio da segunda Guerra Mundial. Me senti num país inimaginável, onde tudo era possível. Me senti feliz, e no Rio não tinha ruínas ${ }^{58}$.

Ideias do Brasil se recompuseram nos escritos de Bo Bardi como quem investigava, descobria e inventava. Seu olhar, em 1956, era já conhecedor da cultura local, a qual, por sua vez, conduzia uma de suas linhas de pesquisa; mas o seu artigo ainda era anterior ao período passado na Bahia, entre 1958 e 1964, e que the possibilitaria um novo encontro com o país.

\section{A descoberta da Bahia}

Para alguns dos italianos imigrados dos quais trata este artigo, a Bahia foi, inicialmente, um mito, lugar onde encontrar um mundo "autêntico", mas também uma segunda descoberta do Brasil.

Em 1952, Sambonet - como assistente do diretor de cinema Gian Gasparre Napolitano - e Bardi - como diretor artístico - foram à Bahia rodar o filme Magia Verde, um documentário sobre o Brasil que apresentava Salvador e lugares de outros estados brasileiros, com o olhar apontado para a natureza, o povo e os seus ritos místicos.

Buffoni, em 1953, imaginava poder pintar as figuras e as paisagens da Bahia, tal como contava a Gatto. Alguns anos mais tarde, em 1958, realizou os painéis dos escritórios da Olivetti em São Paulo, representou aquele lugar e construiu uma imagem do país dentro dos espaços projetados por Palanti, que, por sua vez, retratou a Bahia em fotografias que documentavam o povo - pescadores, baianas, estudantes, a gente no mercado - seus objetos e criações, a paisagem urbana e o jogo de formas e movimento das curvas das igrejas. Mas o encontro mais longo, 
profundo e fecundo foi aquele de Bo Bardi com a Bahia e com o Nordeste brasileiro; e dele surgiram novas ideias do Brasil.

Bo Bardi foi convidada em 1958 a fazer conferências na Escola de Belas Artes da Universidade da Bahia e, em seguida, a colaborar com o professor Diógenes Rebouças no curso de Teoria e filosofia da arquitetura, na mesma universidade. Chamada por Odorico Tavares - jornalista e já autor de artigos para Habitat - contribuiu com o jornal Diário de Notícias de Salvador, do grupo de Chateaubriand, na segunda metade de 1958, com uma página dominical, intitulada Crônicas de Arte, de História, de Costume da Vida ${ }^{59}$.

Em 1959, quando foi fundado oficialmente o Museu de Arte Moderna da Bahia (MAMB), articulado aos Diários Associados e ao conservador poder local, Bo Bardi foi convidada a dirigi-lo, com certo apoio de Bardi e Chateaubriand. Inaugurado em janeiro de 1960, inicialmente no foyer do Castro Alves, foi o lugar onde ela levou adiante uma pesquisa sobre os objetos populares até a sua transferência, em 1963, ao Solar do Unhão, um conjunto arquitetônico do século $X V I I$, restaurado por ela, onde criou, enfim, um Museu de Arte Popular (MAP).

Antes disso, ainda em 1959, junto ao diretor e cenógrafo brasileiro Martin Gonçalves, professor da Escola de Teatro da Universidade da Bahia, Bo Bardi organizou a mostra Bahia no Ibirapuera, para a V Bienal de São Paulo, com a coleção da própria escola. Tratava-se da construção de uma ideia da Bahia a partir da produção do seu povo, na qual se entendia a arte livre de compromissos com a alta cultura. Assim, os autores afirmavam: "Apresentamos a Bahia, poderíamos ter escolhido a América Central, a África, a Espanha e Itália do Sul, qualquer lugar onde não tivesse chegado, ou tivesse sido contida antes de cristalizar-se, a nossa cultura"60.

Para os organizadores, os objetos mostrados possuíam espontaneidade, eram portadores de uma "verdade" e ligados diretamente à vida cotidiana (Figura 6). Tratava-se de uma pesquisa sobre os limites entre arte popular e arte culta, uma alternativa às próprias obras mostradas pela Bienal, capaz de valorizar coisas a que ninguém dava importância, na convicção de que poderiam oferecer, a partir do seu estudo, um caminho para a criação posição não muito diversa daquela de Bardi em Massaguassu.

As fotografias expostas ou projetadas representavam arquiteturas e costumes do povo e eram assinadas por Marcel Gautherot, Silvio Robatto, Ennes Mello e Pierre Verger. Nos dias da exposição, há notícias de terem acontecido apresentações de capoeiristas, de músicos com instrumentos da Bahia, representantes do candomblé e baianas que vendiam doces. A mostra previa espetáculos de Dorival Caymmi e conferências do antropólogo Edson Carneiro e do escritor Jorge Amado.

Bo Bardi e Gonçalves colocavam os objetos em cena como se procurassem reconduzi-los indiretamente aos seus contextos originais - cerâmicas, gaiolas, redes, cestos, bordados para enfeitar as igrejas, imagens de santos barrocos e quadros de procissão, bonecas representando os orixás, carrancas,
59. Ver Juliano Pereira (2008); Zeuler Lima (2013).

60. Cf. Lina Bo Bardi; Martim Gonçalves (1960, p. 32, tradução minha). 


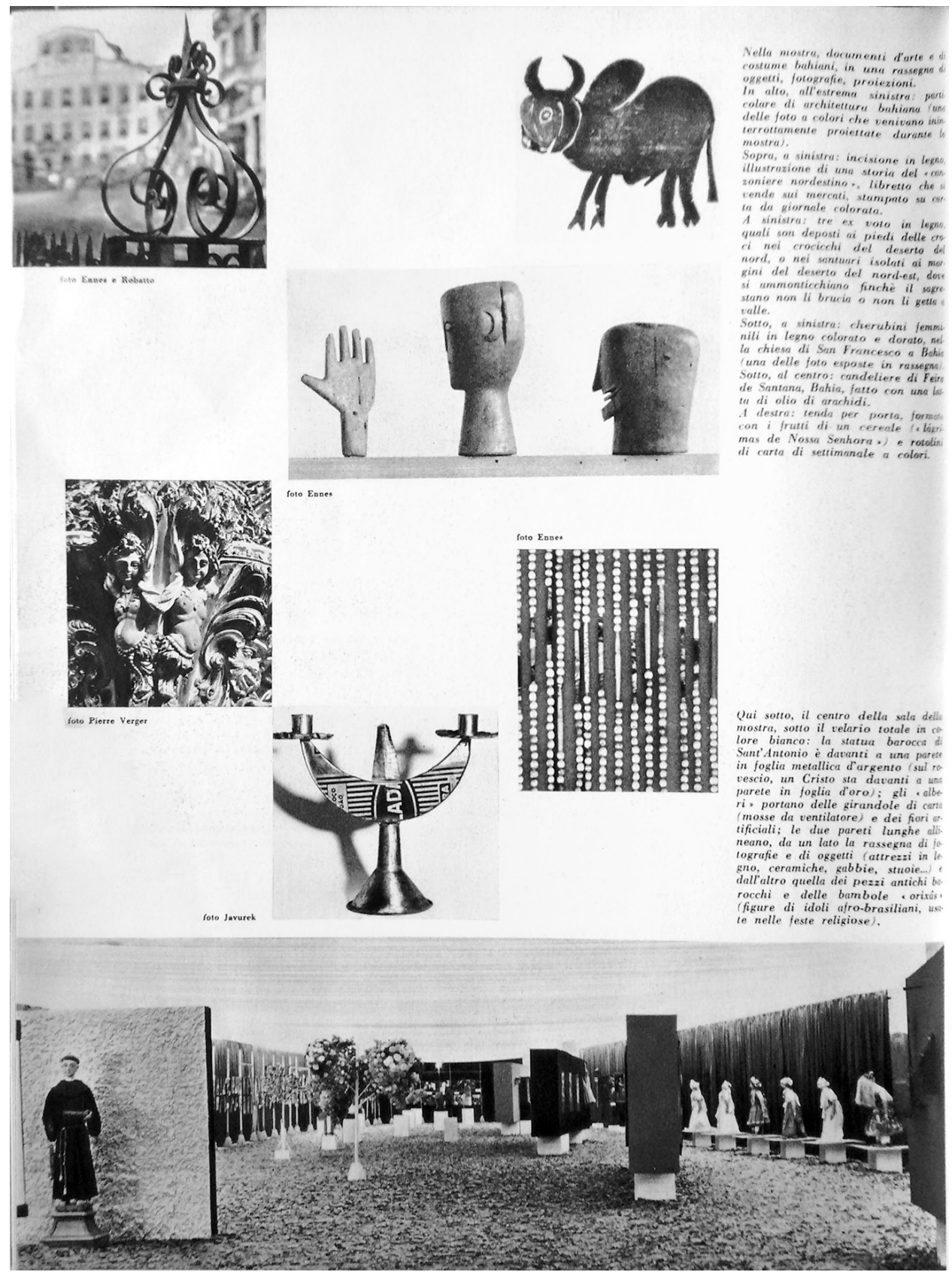

Figura 6 - Página da revista Domus, mar. 1960, apresentando uma imagem da mostra organizada por Lina Bo Bardi e Martim Gonçalves, Bahia no Ibirapuera, São Paulo, 1959, e fotografias e objetos expostos na mesma mostra. Retirado de Domus, mar, 1960, p. 34. (C) Editoriale Domus Spa courtesy of the Publisher.

uma árvore de flores de papel e uma de cata-ventos, movida por um ventilador, entre tantos outros. Pretendiam criar uma "atmosfera", palavra usada no texto de apresentação da mostra para a revista Domus, recorrendo à sinestesia, por meio das cores e do perfume das folhas de eucalipto que cobriam o piso, com as fotografias projetadas, músicas de cantos afro-brasileiros e de instrumentos de percussão, danças e sabores. 
Mas a pesquisa da cultura popular levada adiante por Bo Bardi na Bahia foi tornando-se cada vez mais articulada à ação de um grupo de intelectuais, artistas e políticos brasileiros, nos anos correspondentes ao final do período democrático. Entre seus interlocutores, pareciam comparecer alunos e professores dos cursos da Escola de Teatro, dos Seminários Livres de Música e da Escola de Dança da Universidade da Bahia - que, sob a reitoria de Edgard Santos, transformou-se em um grande centro de atividade artística ${ }^{61}$. Incluíam-se, ao menos inicialmente, também artistas, como Mario Cravo, o já citado jornalista Tavares e personagens da cultura da cidade e de outros estados do Nordeste. Alguns nomes aparecem em seu artigo Cinco anos entre os brancos, nos quais narrou, em 1967, a experiência da Bahia, tornando evidente um sistema de afinidades, escolhas e esquecimentos, com nomes de políticos, economistas, educadores, cineastas, e outros intelectuais. Entre eles estavam Celso Furtado, trabalhando então na Superintendência do Desenvolvimento do Nordeste (SUDENE), e Livio Xavier, diretor do Museu de Arte da Universidade do Ceará, ligado ao Movimento de Cultura Popular (MCP) do Recife, constituído em 1960, e que contava, entre outros, com o educador Paulo Freire, por cujos escritos a arquiteta se interessou. Ela ainda se articulou ao escultor Francisco Brennand, também do Recife. Com ele e Xavier, imaginava levar adiante seu projeto de construção de um inventário da produção popular que pudesse ser a fonte de criação de um design brasileiro, a partir do MAP e da sua não implementada Escola de Desenho Industrial.

Em 1963, na mostra Civilização Nordeste, organizada por Bo Bardi para inaugurar o MAP (Figura 7), foram apresentados, em prateleiras de madeira, objetos de uso cotidiano, construídos com economia e com materiais pobres, embalagens e material de descarte. A pretensão era, ao mesmo tempo, denunciar uma situação e valorizar a criatividade de uma cultura, que criava muito do pouco que possuía. Tal tom de denúncia era diverso da posição de Bardi em Massaguassu. Com a ajuda de Xavier, a essa mostra deveriam estar correlacionadas outras três - que nunca foram efetivadas ${ }^{62}$-, constituindo uma tentativa de leitura da Bahia, e, sobretudo, do Brasil: O Índio; África-Bahia - com a colaboração do fotógrafo Pierre Verger -, e A Europa e a Península Ibérica. Foi Renato Anelli quem, recentemente, observou o quanto os textos de autores brasileiros dos anos 1930 - que propunham interpretações do Brasil a partir das ideias de mestiçagem, como Gilberto Freyre - estão presentes e grifados na biblioteca do casal Bardib3, a corroborar fontes que pareciam guiar as proposições dessas mostras do museu.

As ideias de Bo Bardi pareciam ligadas, também, às palavras de Gramsci, talvez de maneira mais evidente que aquelas de Bardi em Massaguassu: moviam-se do conhecimento das diferenças entre cultura popular e folclore, interessando a arquiteta o papel dado pelo filósofo aos intelectuais nesse campo ${ }^{64}$.

A direção do museu foi interrompida pelos acontecimentos ligados ao golpe militar. A ideia de Brasil que a mostra Civilização Nordeste produzia e que
61. Entre os professores estavam imigrantes, como o maestro alemão Hans Joachim Koellreutter ou a bailarina polonesa Yanka $\mathrm{Ru}$ dzka, herdeiros, de certa maneira, das "conquistas" da arte moderna na Europa, alguns dos quais já conhecidos do casal Bardi, tendo colaborado com o MASP ou com a Habitat. Tratou-se de um momento especial da cultura baiana, ao qual Bo Bardi deu sua especial contribuição. Ver, para tanto, a leitura de Antonio Risério (1995).

62. Ver Juliano Pereira (2008).

63. Exemplos desses livros comparecem à Exposição Lina em Casa: Percursos, Instituto Lina Bo e P.M. Bardi, 12 de abril a 19 de julho de 2015, com curadoria de Renato Anelli e Anna Carboncini.

64. A respeito da relação entre Bo Bardi e Gramsci, ver também Silvana Rubino (2011). 
deveria, em seguida, ser apresentada em Roma ljuntamente a uma exposição fotográfica sobre Brasília) foi censurada pelo governo militar antes da sua abertura, com o intuito de evitar expor ao mundo uma imagem de um país pobre.

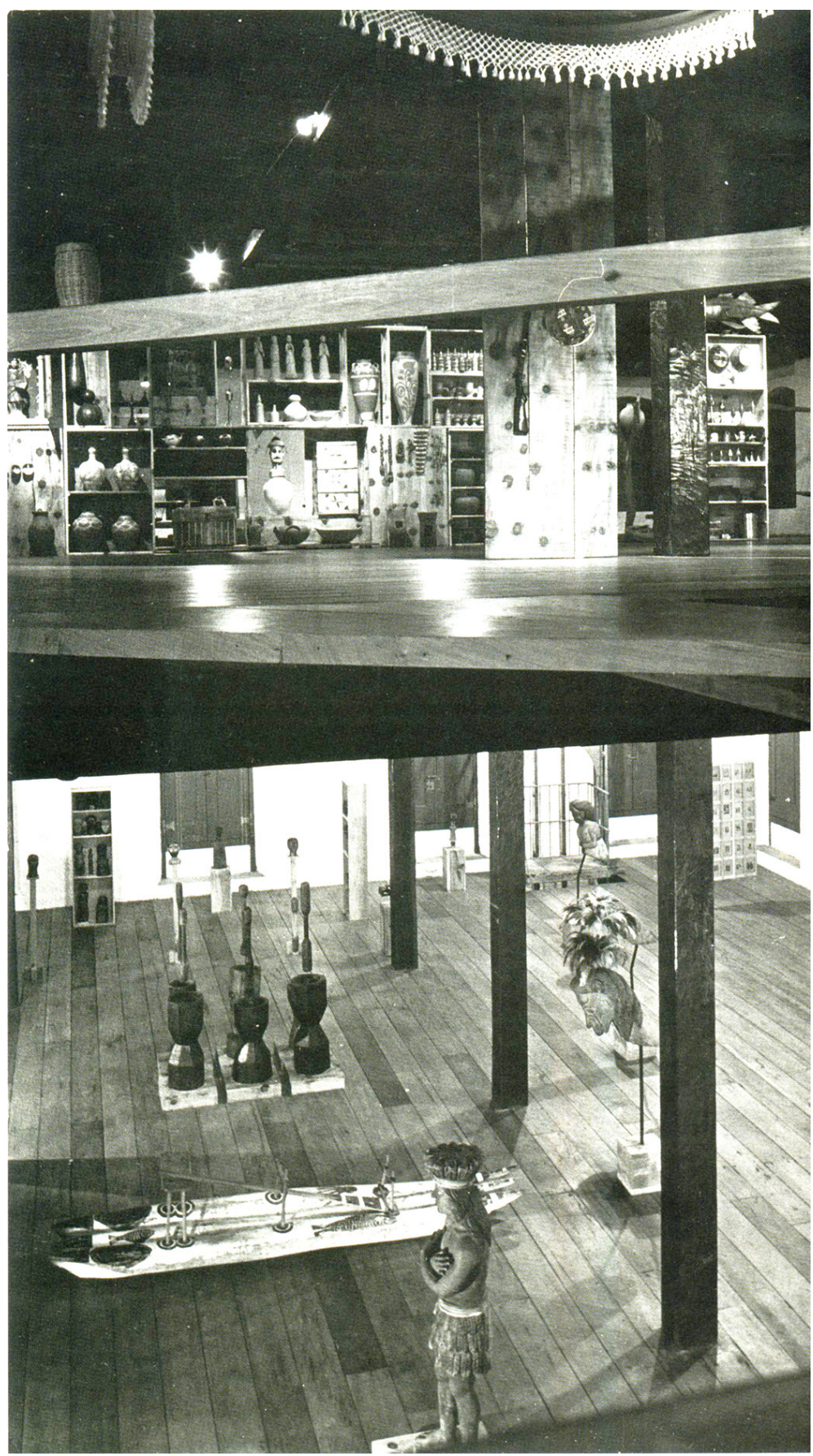

Figura 7- Lina Bo Bardi. Exposição Nordeste, 1963, Salvador, BA Fotografia de Armin Guthmann (C) Instituto Lina Bo e P.M. Bardi/ Armin Guthmann 
Ainda que em modos diversos, interpretar e representar o Brasil, a partir do universo popular e do confronto com a natureza foi um tema presente, como um fio condutor, nas descrições, obras de pintura, gráfica, objetos, fotografias, mostras de Bo Bardi, Bardi, Sambonet, Buffoni e Palanti, avizinhando suas pesquisas, mas, em suas especificidades, distanciando-as.

oceano, visto do alto por Le Corbusier como uma silenciosa separação entre dois mundos, parecia surgir nessas representações como algo vivido de dentro. Um agitado lugar de tensões constantes e um universo de possibilidades, talvez um espaço de ligação entre Europa e América Latina, como aquele representado por uma visão inversa, muito mais recente, explicada pelos olhos de um estudioso latino-americano, Francisco Liernur: Diferentemente de outras áreas do 'terceiro mundo', a América Latina parece apresentar-se às vistas do 'primeiro mundo' como um fenômeno ao qual é ligada: não pertence ao centro, mas é uma de suas extremidades, a borda de um território para o qual o Atlântico é um mar interno"65.

Entre as obras dos personagens citados neste estudo existem grandes diferenças, nem sempre fáceis de definir. Mas se algumas delas mostraram o Brasil como um lugar onde os ideais podiam se desfazer e refazer, elas revelaram, sobretudo, uma dialética entre descoberta e criação, tal como aparecia, por outras vias, em pesquisas de artistas e arquitetos modernos brasileiros. Esse sentido de descoberta nascia aqui de um olhar externo, formado na ltália, em uma situação diversamente marginal, que se reconstituía com o tempo e diante do encontro de uma nova realidade e de novos interlocutores, interessados em deixar-se absorver pelos dilemas da cultura brasileira e fazer-se inserir em seus ambientes. Um olhar que contribuiu, em seus diversos modos, para construir uma nova ideia de Brasil, em termos inéditos de uma pesquisa, de revelação, de promessa e de invenção. 


\section{REFERÊNCIAS}

Il Politecnico di Milano nella storia italiana (1914-1963) (introduzione di Enrico Decleva). v.

1. Roma: Laterza, 1988.

AlMeIdA, Paulo Mendes. De Anita ao Museu. São Paulo: Perspectiva, 1976.

ANELLI, Renato; GUERRA, Abilio; KON, Nelson. Rino Levi: Arquitetura e Cidade. São Paulo: Romano Guerra, 2001.

ANELLI, Renato. Interlocuções com a arquitetura italiana na constituição da arquitetura moderna em São Paulo. 2001. Tese (Livre docência) - Escola de Engenharia de São Carlos, Universidade de São Paulo, São Carlos, 2001.

Ponderações sobre os relatos da trajetória de Lina Bo Bardi na Itália. Pós, Revista do programa de pós-graduação da FAU-USP, São Paulo, v. 17, p. 86-101. 2010.

ARRUDA, Maria Arminda do Nascimento. Empreendedores culturais imigrantes em São Paulo de 1950. Tempo Social, São Paulo, v.17, n.1, p. 135-158, jun. 2005.

BARDI, Pietro Maria. Introdução. In: SAMBONET, Roberto; BARDI, Pietro Maria. Massaguassu: figuras e paisagens no Brasil por Roberto Sambonet. Tradução para o português Mário da Silva. São Paulo: Museu de Arte de São Paulo, 1949, s/p.

BARDI, Pietro Maria; SARAPO, Regina Helena. Exposição Bramante Buffoni, apresentação da exposição ocorrida e financiada pela Italma e Pirelli em São Paulo: catálogo. São Paulo, 1987.

BO BARDI, Lina. Bela criança. Habitat, São Paulo, n. 2, p. 3, 1951.

. Lettera dal Brasile. L'Architettura Cronache e Storia, Roma, n.9, p. 182-187, luglio, 1956.

Curriculum Literário. In: FERRAZ, Marcelo (org.). Lina Bo Bardi. São Paulo: Instituto Lina Bo e P. M. Bardi, 1993. p. 09-12.

BO BARDI, Lina; GONÇALVES, Martin. "Bahia”, esposizione a San Paolo. Domus, Milão, v. 364, n. 3, p. 32-35, mar. 1960.

BONDUKI, Nabil. Origens da habitação social no Brasil. São Paulo: Estação Liberdade, 1999.

BUNÇUGA, Franco. Conversazioni con Giancarlo De Carlo: architettura e libertà. Milão: Elèuthera, 2000. 
CAMESASCA, Elisa. Roberto Sambonet, $i$ luoghi, il tempo e il percorso di una ricerca tra arte e design. 2005-2006. Tese (Graduação) - Facoltà di Lettere e Filosofia, Corso di Laurea in Lettere Moderne, Università degli Studi di Pavia, 2006.

. Biografia. In: MORTEO, Enrico (org.). Roberto Sambonet, design, grafico, artista (19241995). Milão: Officina Libraria, 2008, p. 262-268.

CANAS, Adriano Tomitão. MASP, museu laboratório: projeto de museu para a cidade. 2010. Tese (Doutorado) - Faculdade de Arquitetura e Urbanismo, Universidade de São Paulo, São Paulo, 2010.

CENATI, Roberto; QUATELA, Antonio (org.). Oltre il ponte: storie e testimonianze della Resistenza in Zona 3 - Porta Venezia, Città Studi, Ortica Lambrate.Milão: ANPI Zona3, 2009.

CORATO, Aline Coelho Sanches. Italia e Brasile oltre il. "silenzio di un oceano". Intrecci tra arte e architettura nel Novecento. 2012. Tese (Doutorado). Dottorato in Composizione architettonica, Politecnico di Milano, Milano, 2012.

Art, Architecture and Life: The Interior of Casa de Vidro, the House of Lina Bo Bardi and Pietro Maria Bardi. In: MASSEY, Anne; SPARKE, Penny (org.). Biography, identity and the modern interior. Farnham: Ashgate, 2013, p. 145-158.

DE CLEMENTI, Andreina. Il prezzo della ricostruzione: l'emigrazione Italiana nel secondo dopo guerra. Roma, Bari: GLF editori Laterza, 2010.

FALBEL, Anat. Lucjan Korngold: a trajetória de um arquiteto imigrante. 2003. Tese (Doutorado) - Faculdade de Arquitetura e Urbanismo, Universidade de São Paulo, São Paulo, 2003.

FELDMAN, Sarah. Planejamento e Zoneamento. São Paulo 1947-1972. São Paulo: Edusp/ Fapesp, 2005.

FERNANDES, Fernanda. A experiência do Museu de Arte de São Paulo. A ação de arquitetos e artistas estrangeiros na modernidade paulista. In: $9^{\circ}$ Seminário Docomomo Brasil Interdisciplinaridade e experiências em documentação e preservação do patrimônio recente. Anais eletrônicos... Brasília: UnB/ Docomomo Brasil, 2011a. Disponível em: http://www. docomomo.org.br/seminario\%209\%20pdfs/097_M07_RM-AExperienciaDoMuseuDeArte-ART_ fernanda_fernandes-2.pdf. Acesso em: 20 fev. 2015.

FERNANDES, Fernanda. Deslocamentos Milão-São Paulo: estrangeiros na cidade. In: LANNA, Ana Lúcia Duarte, et al (org.). São Paulo, os estrangeiros e a construção das cidades. São Paulo: Alameda, 2011b, p. 497-520.

FERRAZ, Marcelo (org.). Lina Bo Bardi. São Paulo: Instituto Lina Bo e P. M. Bardi, 1993. 
GALLO, Antonella (org.). Lina Bo Bardi architetto. Catalogo da IX Mostra Internazionale di Architettura della Biennale di Venezia. Veneza: Marsilio, 2004.

GRAMSCI, Antonio (textos); GERRATANA, Valentino (org.). Quaderni del carcere. Torino: Einaudi, 2007. Edição crítica do Istituto Gramsci.

LE CORBUSIER. Precisões: sobre um estado presente da arquitetura e urbanismo. Tradução de Carlos Eugênio Marcondes de Moura. São Paulo: Cosac \& Naify, 2004 [1930].

LÉVI-STRAUSS, Claude. Tristi Tropici. Tradução de Bianca Garufi. Milano: Il Saggiatore, 1982.

LIERNUR, Jorge Francisco. Un nuovo mondo per lo spirito nuovo: le scoperte dell'America Latina da parte dela cultura architettonica del XX secolo. Zodiac, Milão, n. 8, p. 84-121, 1993.

LIMA, Zeuler. Lina Bo Bardi. Prefácio de Barry Bergdoll. New Haven: Yale University Press, 2013.

MARTINS, Carlos Alberto Ferreira. Construir uma arquitetura, construir um país. In: SCHWARTZ, Jorge (org.). Brasil 1920-1950 de la Antropofagia a Brasilia. Valência: Istitut Valencià d'Art Modern, 2000, p. 369-429.

MIOTTO, Laura; NICOLINI, Savina. Lina Bo Bardi: aprirsi all'accadimento. Turim: Testo e Immagine, 1999.

NICOLOSO, Paolo. Genealogie del Piano Fanfani. In: DI BIAGI, Paola. La grande ricostruzione: il Piano Ina-Casa, e l'Italia degli anni cinquenta. Roma: Donzelli, 2001, p. 33-62.

Il contesto sociale politico e universitario di Portaluppi. In: MOLINARI, Luca. Piero Portaluppi, linea errante nell'architettura del novecento. Milão: Skira, 2003, p. 241-249.

OLIVEIRA, Olívia de. Lina Bo Bardi: obra construída. 2G, Barcelona, n. 23-24, 2002.

. Lina Bo Bardi: sutis substâncias da arquitetura. São Paulo; Barcelona: Romano Guerra; Gustavo Gili, 2006.

PARRONCHI, Alessandro. Io, Campo di Marte e l'Ermetismo. L'Unità, Roma, 20 aprile 2004 (impresso na edição de Florença). Disponível em: <http://cerca.unita.it/ARCHIVE/ xml/120000/118202.xml?key=letteratura\&first=731\&orderby=0>. Acesso em: 20 fev . 2015.

PEREIRA, Juliano Aparecido. Lina Bo Bardi: Bahia, 1958-1964. Uberlândia: EDUFU, 2008.

POLITANO, Stela. Exposição didática e vitrine das formas: a didática do Museu de Arte de São Paulo. 2010. Dissertação (Mestrado) - Instituto de Filosofia e Ciências Humanas, Universidade Estadual de Campinas, Campinas, 2010. 
PONTI, Gio. Amate l'architettura. Genova: Vitali e Ghianda, 1957. Republicado como PONTI, Gio. Amate l'architettura: l'architettura è un cristallo. Milão: Rizzoli, 2010 [2008].

POZZOLI, Viviana. 1946! Por que Pietro Maria Bardi decide deixar a Itália e partir para o Brasil? In: Seminário Internacional Modernidade Latina. Os Italianos e os Centros do Modernismo Latino-americano, 2013, São Paulo. Anais eletrônicos... São Paulo: MAC-USP; FAU-USP, 2013. Disponível em: <http://www.mac.usp.br/mac/conteudo/academico/ publicacoes/anais/modernidade/pdfs/VIVIAN_PORT.pdf>. Acesso em: 20 fev. 2015.

RAPPORTO Brasile. Zodiac, Milão, n.6, 1960.

RINALDI, Marco. Arte per l'architettura: Novelli in Brasile (1949-1954). In: VIVARELLI, Pia. Gastone Novelli, 1925-1968. Milão: Skira, 1999, p. 31-39.

RISÉRIO, Antonio. Avant-Gard na Babia. São Paulo: Instituto Lina Bo e P. M. Bardi, 1995.

ROCHA, Angela Maria. Produção do espaço em São Paulo: Giancarlo Palanti. 1991. Dissertação (Mestrado) - Faculdade de Arquitetura e Urbanismo, Universidade de São Paulo, São Paulo, 1991.

RUAS, Isabel. Mosaicos na arquitetura dos anos 50: quatro artistas modernos em São Paulo. São Paulo: Via das Artes, 2014.

RUBINO, Silvana. Gramsci no museu ou a arte popular no Solar do Unhão, Salvador, 1963-64. In: 26a Reunião Brasileira de Antropologia, 2011, Porto Seguro. Anais eletrônicos... Porto Seguro: XXVI RBA, 2011. Disponível em: <http://www.abant.org.br/conteudo/ANAIS/CD_Virtual_26_ RBA/grupos_de_trabalho/trabalhos/GT\%2037/silvana\%20rubino.pdf>. Acesso em: 20 dez. 2014.

RUBINO, Silvana; GRINOVER, Marina (org.). Lina por escrito - textos escolhidos de Lina Bo Bardi. São Paulo: Cosac \& Naify, 2009.

RUSCONI, Paolo. La divulgazione dell'arte contemporânea nelle riviste popolari illustrate di Rizzoli (1931-1934). In: DE BERTI, Raffaele; PIAZZONI, Irene. Quaderni di Acme, v. 115. Milão: Università degli studi di Milano, Facoltà i Lettere e Filosofia, Cisalpino Istituto Editoriale Universitario, 2009, p. 527-573.

SABATINO, Michelangelo. Ghosts and Barbarians: The Vernacular in Italian Modern Architecture and Design. Journal of Design History, Oxford, Inglaterra, v. 21, n. 4, p.35-52, nov. 2008.

SAMBONET, Roberto; BARDI, Pietro Maria. Massaguassu: figuras e paisagens no Brasil por Roberto Sambonet. Tradução Mário da Silva. São Paulo: Museu de Arte de São Paulo, 1949, s/p.

SAMBONET, Roberto; VILLA, Emilio; HUBER, Max. 22 cause più 1. Milão: Ed. Del Milione, 1953. 
SANCHES, Aline Coelho. A obra e a trajetória do arquiteto Giancarlo Palanti. Itália e Brasil. 2004. Dissertação (Mestrado) - Escola de Engenharia de São Carlos, Universidade de São Paulo, São Carlos, 2004.

SAUVAGE, Tristan. Pittura Italiana del dopoguerra (1945-1957). Milano: Schwarz editore, 1957.

SILVA, Joana Mello de Carvalho e. O arquiteto e a produção da cidade: l'esperienza di Jacques Pilon in prospettiva (1930-1960). 2010. Tese (Doutorado) - Faculdade de Arquitetura e Urbanismo, Universidade de São Paulo, São Paulo, 2010.

TENTORI, Francesco. Pietro Maria Bardi: con le cronache artistiche de "L'Ambrosiano" 19301933. Milão: Mazzotta, 1990.

Pietro Maria Bardi. Primo attore del razionalismo. Turim: Testo \& Immagine, 2002.

TISO, Adriana. Giancarlo Palanti. Opere e progetti in Italia 1929-1946. 2009. Tese (Doutorado) - Instituto Universitário de Arquitetura de Veneza, Veneza, 2009.

VITALE, Daniele. Architecture et 'recherche du réel'. Archithese, Zurique, a. 12, n. 6, p. 1418, nov-dez. 1982.

Premessa. In: ; SANCHES, Aline Coelho. Brasile Laboratorio de Architettura, Antologia di testi sull'architettura Brasiliana e latino-americana. Milão: Politecnico di Milano, 2009, p. 7-8.

ZWEIG, Stefan. Brasil, um país do futuro. Prefácio de Alberto Dines. Porto Alegre: L\&PM Pocket, 2008.

\section{DOCUMENTOS CONSULTADOS EM ARQUIVOS}

BUFFONI, Bramante. [Cartas] São Paulo 21 jun. 1953; 23 ago. 1953; 10 nov. 1953; 24 out. 1954; 5 mai. 1955, [para] GATTO, Alfonso. Documentos depositados no Centro Manoscritti - Centro per gli Studi sulla tradizione manoscritta di autori moderni e contemporanei, Università degli studi di Pavia.

Documentos diversos sobre Bramante Buffoni, Pietro Maria Bardi e Roberto Sambonet. Arquivos da Biblioteca e Centro de Documentação do MASP (Museu de Arte de São Paulo), São Paulo.

Documentos diversos. Acervo do Instituto Lina Bo e P.M. Bardi, São Paulo. 
Documentos diversos. Archivio Roberto Sambonet, Milão, hoje localizado no CASVA (Centro di Alti Studi sulle Arti Visive)/ Comune di Milano, Milão.

Documentos diversos e projetos. Acervo da Biblioteca FAUUSP, São Paulo.

Documentos do estudante e professor Giancarlo Palanti. Archivio Storico di Ateneo, Archivi Storici Politecnico di Milano, Milão.

Fotografias de Giancarlo Palanti realizadas no Brasil. Arquivo pessoal do arquiteto junto à família Palanti, Itália.

PALANTI, Giancarlo. [Carta], 1 fev. 1947, São Paulo [para] ALBINI, Franco, Milão. Documento depositado no Acervo da Biblioteca FAUUSP, São Paulo.

\section{ENTREVISTAS REALIZADAS}

Entrevista com Luisa Bernacchi, concedida por telefone para Aline Coelho Sanches Corato, 2010.

Entrevistas com Dirce Maria di Torres, concedida pessoalmente em várias ocasiões para Aline Coelho Sanches Corato, 2008, 2009, 2010, Itália.

Artigo apresentado em 09/01/2016. Aprovado em 10/09/2016. 
